\title{
'Stepping stone' pattern in Pacific Arctic tern migration reveals the importance of upwelling areas
}

\author{
Aly McKnight ${ }^{1, *}$, Andrew J. Allyn ${ }^{2}$, David C. Duffy ${ }^{3}$, David B. Irons ${ }^{1}$ \\ ${ }^{1}$ US Fish and Wildlife Service, Anchorage, Alaska 99503, USA \\ ${ }^{2}$ Department of Environmental Conservation, University of Massachusetts Amherst, Amherst, Massachusetts 01003, USA \\ ${ }^{3}$ Pacific Cooperative Studies Unit, Department of Botany, University of Hawai'i Manoa, Honolulu, Hawaii 96822, USA
}

\begin{abstract}
Arctic terns Sterna paradisaea are noted for their extraordinary migration between Arctic and sub-Arctic breeding grounds and Antarctic wintering areas. Until recently, few data existed to document this migration, and none existed for North Pacific breeders. In this study, we tracked 6 Alaskan Arctic terns tagged with combined light geolocation and saltwater immersion tags through their fall migration. During fall 2007, these birds used several highly productive stopover locations to refuel during their southward migration: the California Current, the northern and southern Humboldt Current, and the Patagonian Shelf. At least 3 of the birds went on to winter in the Weddell Sea region of Antarctica, where Arctic terns from several Atlantic populations are also known to winter. Analysis of the first ever post-breeding behavioral data collected on this species showed that the birds foraged extensively in these staging areas, spending more time foraging on days when they were located within staging areas during the fall migration. We also found that the birds were exclusively diurnal foragers, spending their nights standing out of the water and/or flying. Arctic terns likely face strict time constraints throughout the migration, timing stopovers to match production while simultaneously aiming to arrive at the wintering grounds with sufficient time remaining to complete the winter molt before returning north. Ecological disturbance at any of these locations could have serious consequences for many birds. Further, predicted effects of climate change in the Weddell Sea region could have repercussions throughout the global Arctic tern population.
\end{abstract}

KEY WORDS: Arctic tern $\cdot$ Sterna paradisaea $\cdot$ Migration $\cdot$ Geolocation $\cdot$ Activity sensor $\cdot$ Staging area · California Current · Humboldt Current · Patagonian Shelf · Weddell Sea

\section{INTRODUCTION}

Migrating birds face a number of challenges in their travels between breeding and wintering sites. Long-distance travel is demanding; birds must either accumulate substantial energy reserves before commencing migration, locate sufficient foraging areas along the way to meet the energetic requirements of migration, or strike a balance between the 2 strategies to optimize their body mass for sustained flight (Klaassen 1996). Foraging itself can be problematic; seabirds often rely on complex strategies for locating

*Email: aly.mcknight@gmail.com and capturing prey (Hunt et al. 1999) and may need to adjust their foraging tactics and diets as they migrate through vastly different oceanic environments. As an added complication, weather, particularly local wind events, can affect both the migratory route as well as the pace of migration (Liechti 2006). The pace of migration may be acutely important for those seabirds whose arrival on the wintering grounds must precede the beginning of their winter molt (Voelker 1997), a period during which a bird's flight (Hedenström \& Sunada 1999) and thermoregulatory abilities (Hahn et al. 1992) can be hampered. 
While every migratory bird species must grapple with these issues to some extent, their effects could be compounded for a species such as the Arctic tern Sterna paradisaea, a small surface-feeding seabird that makes a remarkable annual migratory journey from Arctic and sub-Arctic breeding grounds to wintering grounds in the Antarctic (Salomonsen 1967, Hatch 2002). Although its global population size likely lies between 1 to 2 million breeding pairs (Hatch 2002) or more (Ratcliffe 2004), there are indications that some populations have undergone recent declines, notably in Greenland (Hansen 2001), the northeastern USA (Kress 1983, Gulf of Maine Seabird Working Group unpubl.), and the Gulf of Alaska (Stephensen et al. 2002, Denlinger 2006, McKnight et al. 2008).

Although many studies have addressed factors relating to the breeding biology of Arctic terns at colonies throughout their circumpolar distribution (e.g. Chapdelaine et al. 1985, Devlin et al. 2008, Heinänen et al. 2008, Wanless et al. 2009), comparatively few have investigated migratory behavior and wintering locations of specific breeding populations. Egevang et al. (2010) showed that tagged Arctic terns from colonies in Greenland and Iceland wintered primarily in the Weddell Sea area, with no obvious segregation of breeding populations; in contrast, Fijn et al. (2013) found that a small sample of Arctic terns tagged in the Netherlands wintered in the Eastern Antarctic. Virtually nothing is known about post-breeding dispersal and wintering behavior of Pacific populations. At-sea surveys of the Southern Ocean during the austral summer have revealed that wintering Arctic terns can occur throughout the region and are closely associated with icebergs and the pack ice edge (Veit \& Hunt 1991).

In this study, we used combined geolocator and activity dataloggers to investigate the southward migration paths, wintering locations, and activity patterns of Arctic terns from a colony in south-central Alaska. Because all but one of the devices failed prior to commencement of the spring migration, we were unable to investigate return travel patterns.

\section{MATERIALS AND METHODS}

\section{Deployment and retrieval of dataloggers}

We used box and spring traps to capture and tag 20 Arctic terns with combined geolocator and saltwater immersion tags (Model Mk14, British Antarc- tic Survey) in July 2007 at a small colony of approximately 80 terns in Harriman Fjord, in northwestern Prince William Sound, Alaska $\left(61^{\circ} 00^{\prime} \mathrm{N}, 148^{\circ} 20^{\prime} \mathrm{W}\right)$. We affixed each $1.5 \mathrm{~g}$ data logger to a Darvic leg band using 2 ultraviolet-resistant cable ties. At ca. $2.5 \mathrm{~g}$, the combined mass of logger, leg band, and cable ties represented less than $3 \%$ of the body mass of even the smallest study bird and thus were within acceptable mass limits for devices attached to seabirds (Phillips et al. 2003), although we were unable to test for any negative aerodynamic (cf. Vandenabeele et al. 2011) or breeding consequences of the devices (e.g. Nisbet et al. 2011). In fact, because of the remote location of the nesting colony, we were unable to determine nesting phenology or success rates in either study year. We retrieved 4 of the 20 tags in June 2008 and an additional 2 tags in June 2009. Our device retrieval rate was somewhat greater than retrieval rates reported by Egevang et al. (2010) (Arctic Greenland: 10 of 50 devices retrieved; Arctic Iceland: 1 of 20 devices retrieved), but substantially lower than that reported by Fijn et al. (2013) (5 of 7 devices retrieved). Low retrieval rates resulted from an apparently poor nesting effort in 2008, which was anomalously cold. We detected several birds carrying tags that proved impossible to recapture at the nest, as they were not incubating. We downloaded the data from the devices onto a PC through an interface box provided by the British Antarctic Survey.

The tags sampled light levels once per minute, measured using an arbitrary, truncated scale developed by the British Antarctic Survey (Phillips et al. 2004). The maximum light level for each 10 min interval was then recorded. Salt water immersion was assessed every $3 \mathrm{~s}($ dry $=0$, wet $=1)$, and the total number of wet readings was logged for each $10 \mathrm{~min}$ period, up to a maximum value of 200 when the tag was continuously submerged.

\section{Analysis of light data \\ Daily locations}

We processed the data collected by each geolocator following the method described by Phillips et al. (2004), using software provided by the British Antarctic Survey to decompress each data file, edit out unreliable transition data, and calculate latitudes and longitudes for noon and midnight each day using day/night length and the times of sunrises and sunsets, respectively. We used a combination of both 
ground-based and bird-based (during a period when tagged individuals were known to be attending the colony) calibration data as well as recommendations from British Antarctic Survey staff (J. Fox pers. comm.) regarding device specifications. We first determined daily transition times using the most appropriate light threshold value (10 light units) and used transition times to calculate position using the most appropriate sun elevation value $\left(-4.75^{\circ}\right)$.

We used several filters in order to ensure that only the most reliable positions would be used in the ultimate analysis. First, we did not calculate positions for any day or night when shading events rendered sunrise or sunset times uncertain. We also removed all data from dates within $20 \mathrm{~d}$ of an equinox, as equal day length across latitudes at this time precludes latitudinal determination from day length alone. Using spherical trigonometry to calculate distances between consecutive position fixes, we also removed positions requiring flight speeds of $>65 \mathrm{~km} \mathrm{~h}^{-1}$ sustained over a $24 \mathrm{~h}$ period, as such high sustained velocities seemed unlikely for a small tern (Spear \& Ainley 1997). In addition, several birds traveled far enough south for periods in November to January to experience continuous $24 \mathrm{~h}$ light periods; position determination was obviously impossible during these times. These filtering activities resulted in the removal of an average of 78 dates per bird between 20 July 2007 and either 28 February 2008 or the date of last useable position data.

We smoothed the remaining data over $3 \mathrm{~d}$ periods, using the moving average technique to calculate the smoothed latitudes and longitudes, before importing them into ArcGIS v.9.3 (ESRI 2008) in the WGS 84 coordinate system and an equidistant cylindrical projection.

\section{Staging areas vs. travel corridors}

We identified staging areas to include any positions where latitudinal movements were $<0.8^{\circ}$ over a $12 \mathrm{~h}$ period, smoothed over $3 \mathrm{~d}$ (Egevang et al. 2010, Stenhouse et al. 2012). These areas included both migratory stopover regions as well as the colony region and wintering ground. All other points were designated as 'travel corridor' positions. Next, we imported the position data into ArcGIS v.9.3 using an equidistant cylindrical projection. We generated a kernel density distribution (cell size $=50 \mathrm{~km}$, search radius $=250 \mathrm{~km}$ ) of all staging area positions using the ArcGIS Spatial Analyst Kernel Density tool, which employs a quadratic kernel function.

\section{Monthly habitat use analysis}

In addition to using a kernel density distribution to delineate broad staging areas, we also generated monthly kernel density distributions of staging and travel points (cell size $=50 \mathrm{~km}$, search radius $=$ $250 \mathrm{~km}$ ) in order to assess birds' locations with respect to monthly marine productivity data. To investigate this relationship, we performed 2 comparisons. First, we compared ocean productivity between staging areas $(95 \%$ kernel density contours of all staging points) and travel areas (95\% kernel density contours of all travel points) for the months of August, October, and November 2007. Then, to further examine the birds' habitat use within staging areas, we also compared ocean productivity between the core staging areas $(75 \%$ density contour of all staging points) and the general staging range (75 to $95 \%$ density contours of all staging points) (e.g. Pinet et al. 2011). We assumed that higher productivity would result in more abundant food for the migrating terns. However, we have no data on Arctic tern diets during migration in the Pacific to test this assumption.

In order to make these comparisons, we determined the median productivity value for each region described above. To this end, we overlaid each polygon onto the corresponding monthly ocean productivity dataset (1/6 degree grid) downloaded from Oregon State University's Ocean Productivity Site (equidistant cylindrical projection) (www.science. oregonstate.edu/ocean.productivity/index.php, Behrenfeld \& Falkowski 1997) and extracted all productivity values from within each polygon. Grid cells with no productivity data were omitted from the analysis. Because productivity values were not normally distributed, we calculated the median productivity value for each polygon for each month and used a non-parametric bootstrap ( $\mathrm{N}=10000)$ (Efron \& Gong 1983) created in Program R (R Core Development Team 2012) to calculate $95 \%$ confidence intervals around each monthly contour median productivity point estimate. To evaluate the difference in median productivity values between travel vs. staging areas and between general staging range vs. core staging areas, we calculated the difference in median productivity values between each region at each bootstrap iteration. We assumed that the median productivity values were significantly different between the regions if $95 \%$ of the distribution (i.e. the interval between the $2.5 \%$ and $97.5 \%$ quantiles) of the differences between the median productivity values did not include zero. 
In November to February, when the birds traveled farther south than the southern limit of the ocean productivity data, we overlaid monthly bird staging positions onto monthly ice extent data (25 km grid) downloaded from the National Snow and Ice Data Center and projected in the equidistant cylindrical projection (http://nsidc.org/, Fetterer et al. 2009).

In order to assess the apparent day lengths experienced by migrating terns, we determined the total duration of 'full light' conditions (light level $=64$ units, roughly equivalent to conventional day length) recorded for each bird on each day of deployment. For this exercise, we included data from all dates, even those that had been filtered out for location analysis, as our investigation of general day length did not require the minute-level precision necessary for position determination. We averaged the day lengths in hours for all available birds on each date between 20 July 2007 and 29 February 2008, then calculated and graphed average weekly values for this time period.

\section{Analysis of activity data}

We identified 3 types of behavior from the saltwater immersion data: (1) 'floating,' which occurred when the logger was submerged for at least one 10 min period, indicating that the bird was sitting on the water; (2) 'flying/standing,' which occurred when the logger was entirely dry for at least one $10 \mathrm{~min}$ period, as would occur when a bird was flying or standing on land or on floating ice or debris; and (3) 'possible foraging,' which occurred when the logger recorded intermittent wet and dry states for at least one 10 min period (McKnight et al. 2011).

Arctic terns forage by plunge-diving into water $(<50 \mathrm{~cm})$ from the air, diving-to-surface (involving partial immersion), or contact dipping (Hatch 2002). As both plunge-diving and diving-to-surface involve actively transitioning from air to water, this behavior would most likely be logged as intermittent wet-dry activity. Contact dipping, in contrast, allows terns to take prey without immersion (Ashmole \& Ashmole 1967), and thus may be under-represented in our foraging behavior category. Intermittent wet-dry records likely also included non-foraging behaviors (e.g. preening, intensive scratching or stretching while floating on the water). Despite these issues, and in the absence of at-sea behavioral time budget data for Arctic terns, we believe that intermittent wet-dry records can serve as a reasonable approximation of relative time spent foraging.
Because immersion data were assessed over 10 min intervals, we chose to eliminate possible foraging (hereafter 'foraging') records that occurred during only one 10 min period between a floating period and a flying/standing period (or vice versa). Such records most likely indicated that the bird made the transition from floating to flying/standing (or vice versa) during that transitional $10 \mathrm{~min}$ period, and was not foraging. Also, to account for incidental behaviors such as scratching and stretching that might cause intermittent dry readings while the bird was otherwise floating on the water, we classified any activity record of 195 or greater (out of the maximum value of 200 for any 10-min period) as 'floating,' typically a rare activity among Arctic terns (Hatch 2002). Activity records of 1 to 194 were therefore classified as 'foraging,' and generally included multiple transitions between the dry and wet states; activity records of 0 were designated as 'flying/standing' behavior.

We calculated the duration in minutes (multiples of 10) for each behavior on every day of logger deployment for each bird. Because activity data were collected independently of the light data, loggers recorded useable activity data even during time periods that were filtered from the position data, including time spent in continuous daylight during the austral winter. Using the light data recorded at simultaneous intervals, we grouped behaviors into 'night' (recorded light level $=0$ ) and 'day' (maximum recorded light level $=64$, achieved $<30$ min after sunrise even on days with heavy cloud cover) for each day of deployment. We excluded activities that occurred during transitional light levels ('twilight') in comparisons of daytime vs. nighttime activity patterns. We calculated the average number of minutes per day that each bird spent in floating, flying/standing, and foraging activities by month between 1 August 2007 and 29 February 2008. We also calculated the average duration of daytime flying/standing and foraging bouts by month for each bird during the same time period.

To examine monthly patterns in behavior, we compared (1) the average number of hours spent per day in floating, flying/standing, and foraging, and (2) the duration of daytime flying/standing and foraging bouts among all months. To make the comparisons, we used Program R ( $\mathrm{R}$ Core Development Team 2012) to first generate a mixed linear effects model, with month as a fixed effect and bird as a random effect, with the lmer function in the lme4 library (Bates et al. 2011) to determine whether significant monthly differences existed. When warranted, we then performed multiple comparisons with the glht 
function in the multcomp library (Hothorn et al. 2008) to test which pairs of months were significantly different using Tukey's HSD tests $(\alpha=0.05)$.

To identify differences in behavior between days that birds spent within staging areas vs. days that the birds were traveling, we first calculated the average hours per day each bird spent flying/standing and foraging in staging areas vs. traveling corridors each month for August 2007 to November 2007. Because this determination required useable position data, we used only the subset of behavior data occurring on days with reliable geographic fixes. We chose to include both daytime and twilight records in this analysis in order to capture all possible foraging activity; the previous analysis had indicated that very little foraging occurred at night. We omitted data from months after November, as several birds traveled into regions of continuous daylight and therefore beyond the scope of our ability to determine locations. We tested for a significant effect $(\alpha=0.05)$ of month on average time spent for each behavior in staging areas vs. traveling days using a linear effects model with month as a fixed effect and bird as a random effect. We implemented this linear mixed effects model using the lmer function in the lme4 library (Bates et al. 2011). We then evaluated month-to-month comparisons using the glht function in the multcomp library (Hothorn et al. 2008) and Tukey's HSD tests $(\alpha=0.05)$.
Delineating staging areas based on reduced latitudinal movements allowed us to identify several important coastal regions used by all or most of the tagged birds, including 4 stopover regions and 2 regions used as wintering grounds (Fig. 1). From the colony region in south-central Alaska, the birds all travelled $\sim 2500 \mathrm{~km}$ to the first stopover region within the California Current off the coasts of Oregon and northern California ( 46 to $35^{\circ} \mathrm{N}$ ), where several birds remained for 2 to $4 \mathrm{wk}$ in August. From there, the birds continued southward for $7000 \mathrm{~km}$ to a stopover region in the northern Humboldt Current off the coast of Ecuador and Peru $\left(5^{\circ} \mathrm{N}\right.$ to $\left.18^{\circ} \mathrm{S}\right)$. This portion of the migration overlapped substantially with the equinox filtering period, so the precise dates of attendance are unavailable for most birds. Four of the tagged birds were already present in the region by the end of August; the other 2 birds arrived during the equinox filtering period and remained in the area until the third week of October. After leaving this stopover area, 3 of the birds then travelled an additional $2700 \mathrm{~km}$ south to a secondary stopover location close to the Chilean coast ( 28 to $41^{\circ} \mathrm{S}$ ) during mid- to late October, while 2 continued on directly to the next stopover location. All 5 birds crossed eastwards over the Andes (Duffy et al. in press) to reach a final stopover location off the Argentinian coast near the convergence of the Brazil and Malvinas Currents

\section{RESULTS}

Of the 6 geolocator tags that we retrieved, only 1 remained functional throughout the entire deployment (bird 6228); the others failed between October 2007 and March 2008. Five of the 6 birds left the colony region within a 2 wk period between 24 July 2007 and 7 Aug 2007; the sixth bird left the colony region 7 d later, on 15 Aug 2007. Upon reaching the Southern Ocean, 3 of the birds spent substantial periods of time in regions with continuous daylight (bird 6212: $2 \mathrm{wk}$; bird 6228: $5 \mathrm{wk}$; and bird 6222: $12 \mathrm{wk}$ ); fixes for these birds were therefore unavailable during these periods (see Table S1 in the Supplement at www.int-res.com/articles/ suppl/m491p253_supp.pdf). Bird 6228 appeared to have commenced its spring migration during the period of unreliable position determination around the spring equinox and arrived back in the colony region by 1 May 2008 .

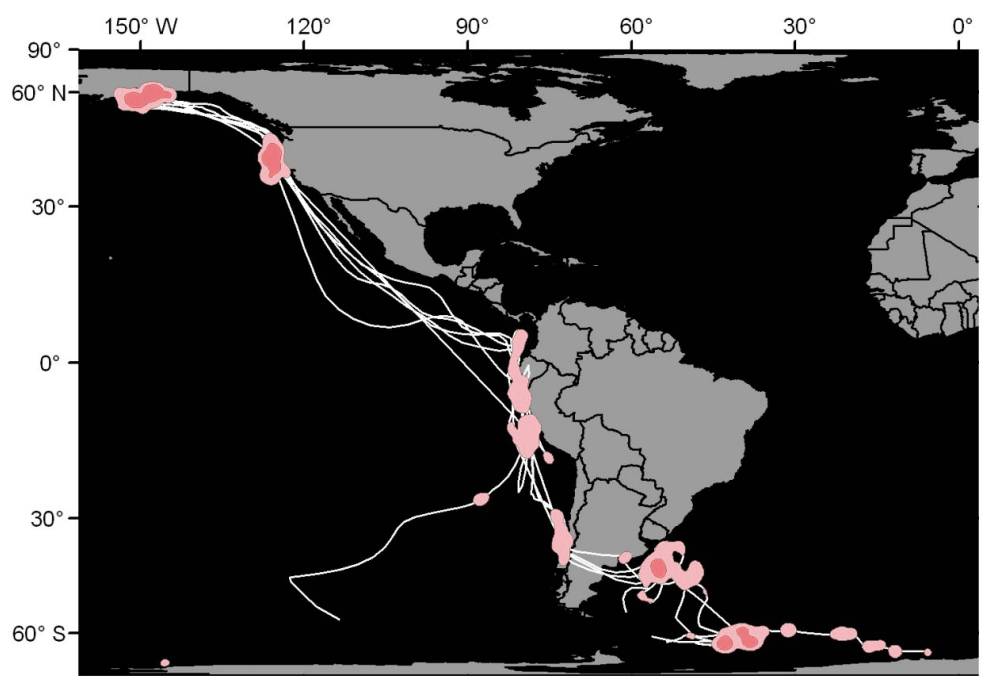

Fig. 1. Sterna paradisaea. 'Staging areas,' including the colony region, stopover locations, and wintering grounds, represented here by the $95 \%$ (light pink) and $75 \%$ (dark pink) kernel density contour polygons of all bird positions displaying $<0.8$ degrees change in latitude over a $12 \mathrm{hr}$ period, smoothed over $3 \mathrm{~d}$ (Stenhouse et al. 2012). 'Travel corridors' (white lines) represent bird paths between staging areas, when latitude changed by $\geq 0.8$ degrees of latitude over a $12 \mathrm{hr}$ period. We assumed straight travel paths between consecutive points 
(35 to $48^{\circ} \mathrm{S}$ ), where they remained until mid-November, before proceeding south to the wintering grounds. After mid-November, 4 of the birds wintered at least for a time along the ice edge in the Weddell Sea region; some of the birds traveled even further south, as evidenced by several tags that recorded 24 $\mathrm{h}$ of continuous daylight for substantial periods of time during the austral summer. A fifth bird traveled west to a wintering region near the boundary of the Amundsen and Ross Seas. Wintering positions were unavailable for the sixth bird due to its mid-October tag failure (Fig. S1 in the Supplement at www.intres.com/articles/suppl/m491p253_supp.pdf).

Examination of the bird location data with respect to ocean productivity in August to November (Fig. 2) showed that the ocean productivity was highest within staging areas for each month, ranging from a bootstrapped median value of $\sim 680$ to $\sim 860 \mathrm{mg} \mathrm{C} \mathrm{m}^{-2}$ $\mathrm{d}^{-1}$ within staging areas vs. $\sim 310$ to $\sim 670 \mathrm{mg} \mathrm{C} \mathrm{m}^{-2}$ $\mathrm{d}^{-1}$ within travel corridors. Ocean productivity was
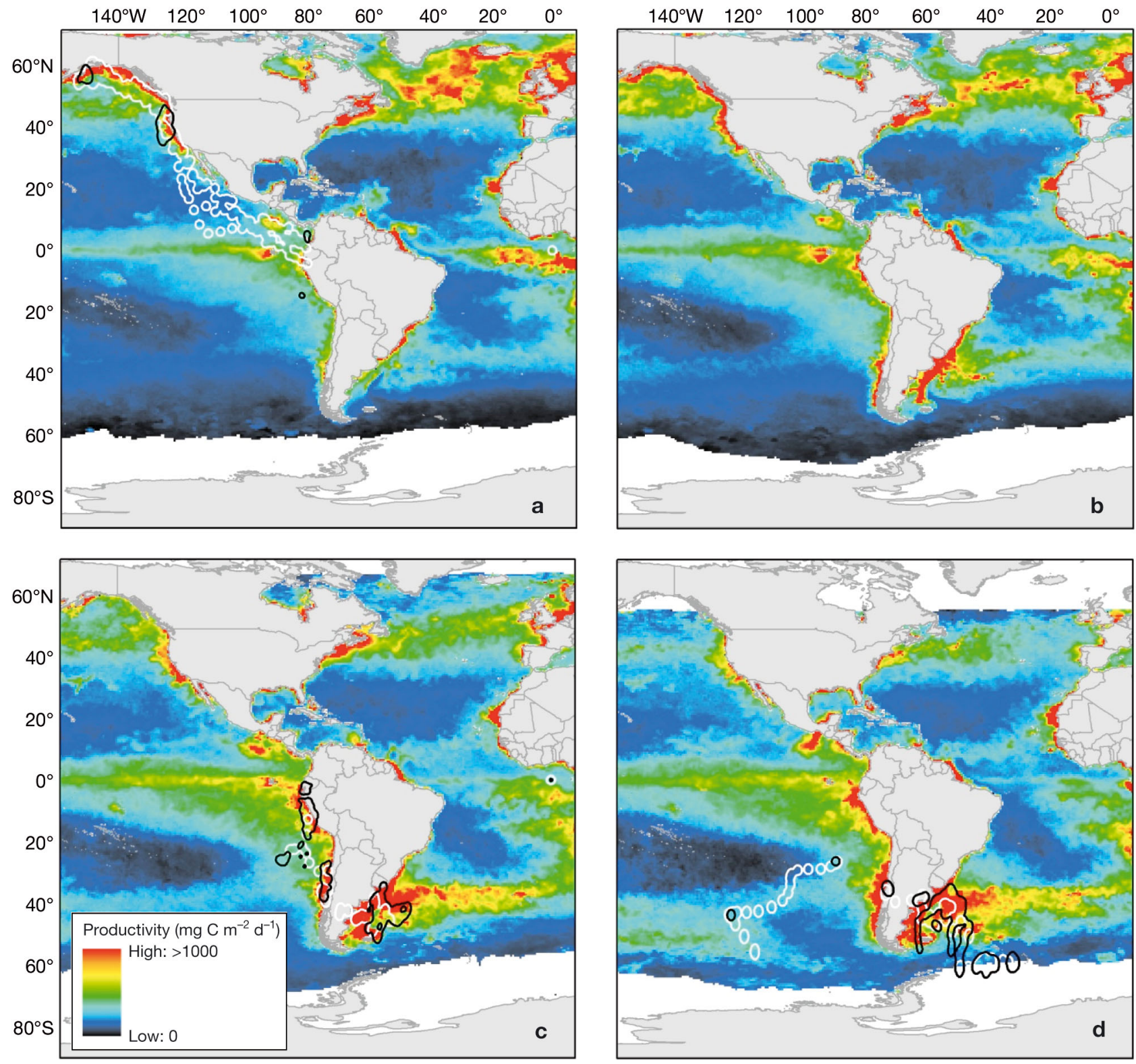

Fig. 2. Sterna paradisaea. 95\% kernel density contour polygons for monthly staging (black borders) and travel corridor positions (white borders) overlaid on monthly ocean productivity data for (a) August, (b) September, (c) October, and (d) November. Although there are no bird positions available for September because of equinox filtering, we include the ocean productivity data here to illustrate the seasonal southward progression of productivity zones during the terns' migration period 
also higher in the core staging range compared to the general staging range for each month, ranging from a bootstrapped median value of $\sim 1020$ to $\sim 1050 \mathrm{mg} \mathrm{C}$ $\mathrm{m}^{-2} \mathrm{~d}^{-1}$ within core staging range vs. $\sim 580$ to $\sim 790 \mathrm{mg}$ $\mathrm{C} \mathrm{m}^{-2} \mathrm{~d}^{-1}$ within the general staging range (Fig. 3). None of the $95 \%$ confidence intervals of the differences between bootstrapped median productivity values for the core and general staging ranges overlapped zero, indicating that for every comparison, the difference in productivity was statistically significant.

Although productivity data were unavailable for the wintering grounds, examination of bird staging positions from November to February with respect to sea ice data revealed that during this period, birds were located primarily in regions with substantial sea ice cover (Fig. S2 in the Supplement).

Tagged birds exhibited different behavior patterns in staging areas vs. traveling corridors. In general, birds spent more days in staging areas than in travel

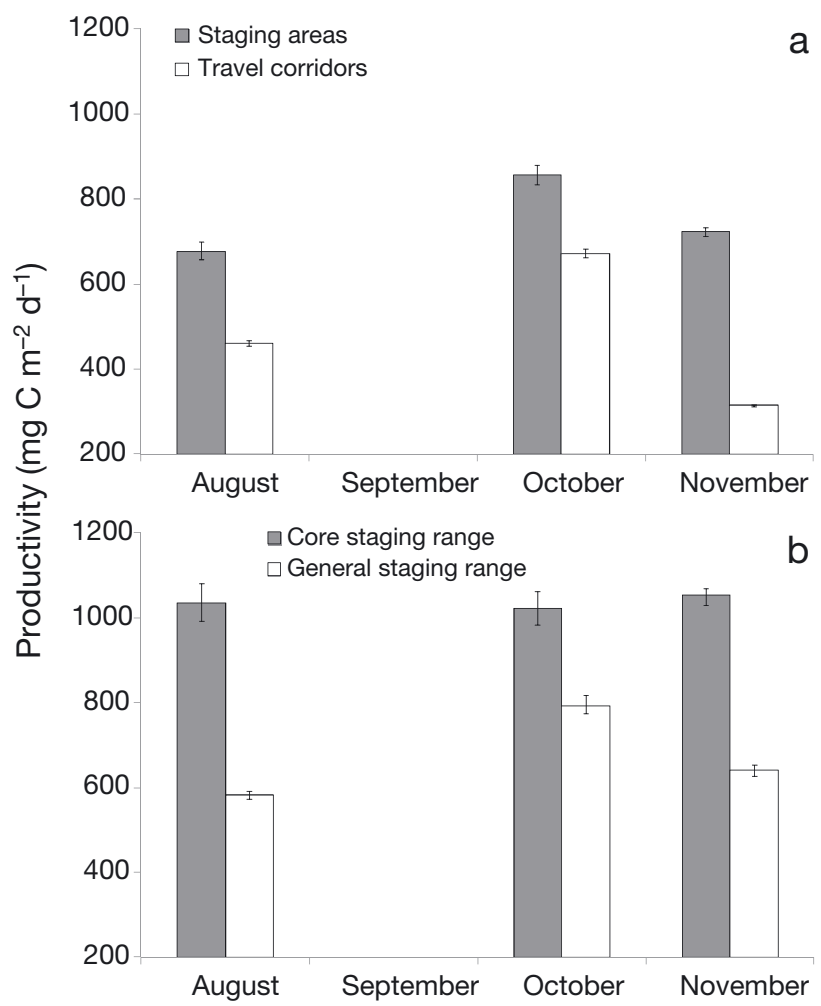

Fig. 3. Bootstrapped median values of ocean productivity within (a) the $95 \%$ kernel density contours for staging areas vs. travel corridors and (b) the core staging range (75\% kernel density contours) vs. the general staging range (excluding the core range; 75 to $95 \%$ kernel density contours). Error bars depict the 2.5 and $97.5 \%$ quantile boundaries of each bootstrapping distribution. All comparisons were significant at the $\alpha=0.05$ level. September data are omitted because position determination was unreliable within $20 \mathrm{~d}$ of the fall equinox corridors among all dates with useable position data (Table S2). Although the lack of position data during the period of the fall equinox rendered analysis impossible for September, we found that birds spent significantly more hours per day foraging on days when they were located within staging areas than they did during travel corridor days in both August and October (Fig. 4, Table S3).

During the study period, tagged birds never experienced days with fewer than $12.5 \mathrm{~h}$ of daylight, according to geolocator records of the daily durations of full daylight conditions (Fig. S3). The larger subset of activity data, which included all dates regardless of the usability of the corresponding position data, revealed that the birds foraged almost exclusively during these daylight hours and spent the overwhelming majority of nighttime hours standing or flying (Fig. 5). Results of linear mixed effects modeling suggested that birds spent more time foraging during the migration than they did upon arrival to the wintering grounds, though specific month-to-month comparisons were statistically insignificant. Tagged birds spent significantly more time per day in flying/ standing behavior during November to January than during August to October, and more time floating on the water's surface in August than in other months (Table S4).

Flying/standing and foraging bout lengths also varied among months. Mean flying/standing bouts ranged from 29 to $66 \mathrm{~min}$ and were significantly longer in the austral summer months than in midmigration months (September to October). Foraging bouts ranged from 21 to $29 \mathrm{~min}$ on average, and while specific month-to-month comparisons of foraging bout length were statistically insignificant, linear mixed effects modeling suggested that foraging bouts were longer during the migration months than during the wintering period (Fig. 6, Table S5).

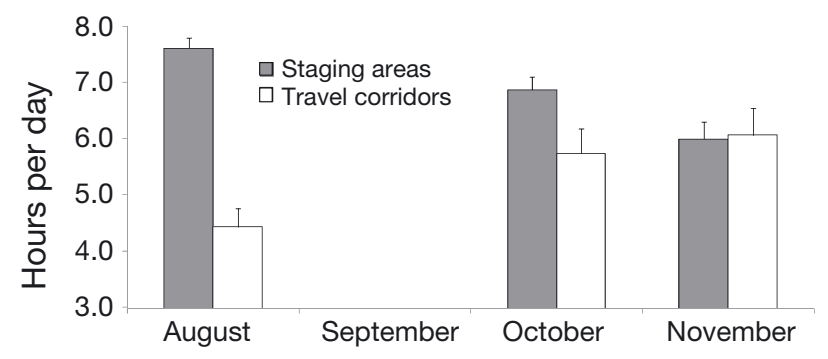

Fig. 4. Sterna paradisaea. Hours per day spent foraging in staging areas vs. travel corridors by month, averaged across all birds. Only dates with reliable positions were used. September data are omitted because position determination was unreliable within $20 \mathrm{~d}$ of the fall equinox. Error bars denote standard error 

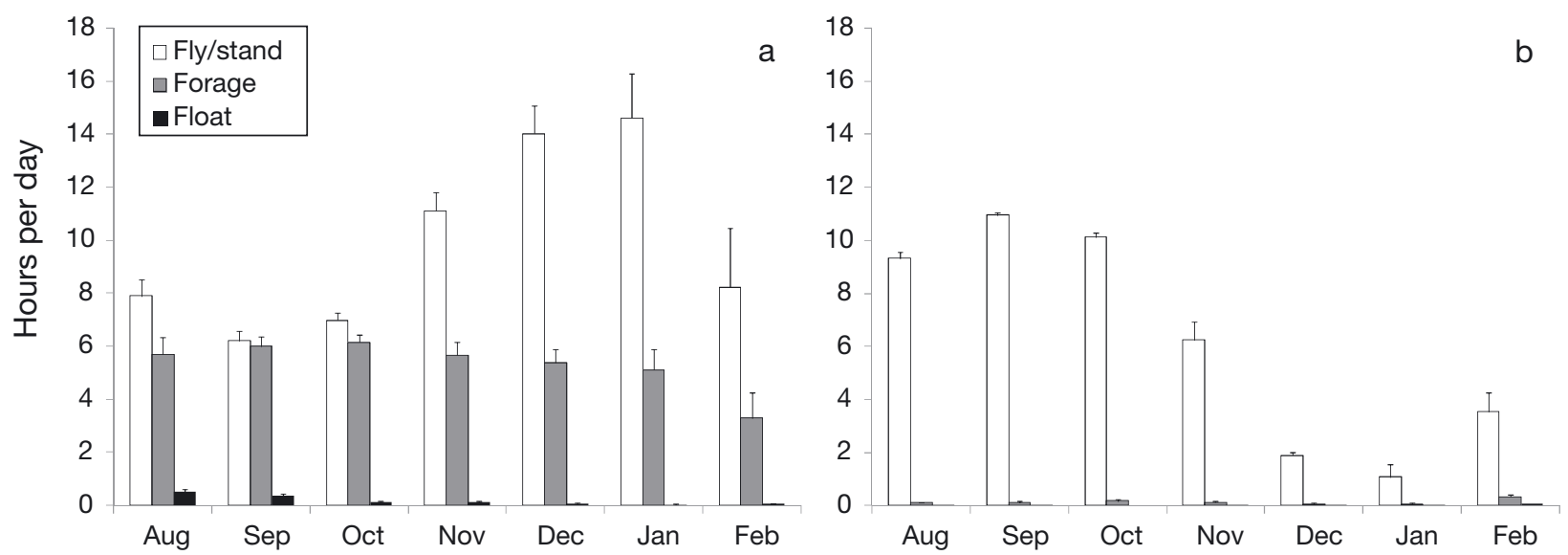

Fig. 5. Sterna paradisaea. Average number of (a) daylight hours and (b) nighttime hours spent in flying/standing, foraging, and floating behaviors by month. We omitted behavior during twilight periods. Means were first computed for individual birds, then the means were averaged across all birds. Error bars denote standard error. August to October: $N=6 ;$ November to January: $\mathrm{N}=5$; February: $\mathrm{N}=3$

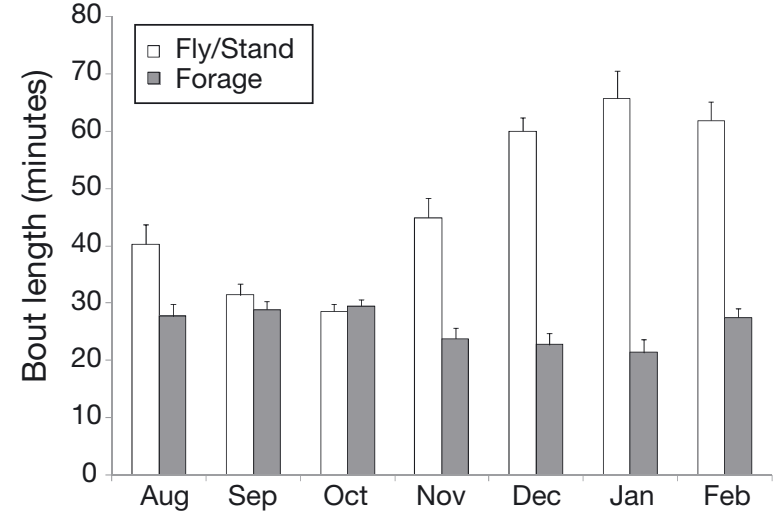

Fig. 6. Sterna paradisaea. Average duration in minutes of daytime flying/standing and foraging bouts by month. Twilight periods were excluded from this analysis. Means were first computed for individual birds, then the means were averaged across all birds. Error bars denote standard error. August to October: $\mathrm{N}=6$; November to January: $\mathrm{N}=5$; February: $\mathrm{N}=3$.

\section{DISCUSSION}

This is the first study to provide data on postbreeding season movement and activity patterns of Arctic terns from a known breeding site in the North Pacific. We were able to identify several important regions, including stopover and winter-use regions, for 6 Arctic terns from Prince William Sound, Alaska.

Given the tremendous distances traveled by Arctic terns during their southward migration, staging areas appear to serve as migratory 'stepping stones' to maximize the birds' refueling potential at a few key locations during their journey south. This strategy has been well-documented in many migratory bird groups, including waterfowl (e.g. Lehikoinen \& Jaatinen 2012), shorebirds (e.g. Tsipoura \& Burger 1999), land birds (e.g. Dunn 2002), and seabirds (e.g. Stenhouse et al. 2012), including Arctic terns breeding in the Atlantic (Egevang et al. 2010). Our behavioral data lend support to the idea that the birds used these stopovers as refueling opportunities, as foraging behavior was more prominent within staging areas than within travel corridors. All of the migratory stopover areas we identified occurred within areas experiencing major coastal upwelling, and core stopover regions (75\% kernel density contours) exhibited significantly greater productivity than the general range of stopover locations (75\% to $95 \%$ kernel density contours). Positions derived from light geolocation offer relatively low accuracy; at best, fixes are accurate to within $185 \pm 114 \mathrm{~km}$ for flying seabirds at mid-latitudes (Phillips et al. 2004), and they are likely even less accurate in equatorial regions (e.g. Nisbet et al. 2011). Despite this issue, the fact that we observed a clear relationship between core stopover regions and ocean productivity suggests that the true relationship between staging areas and productivity hotspots may be even stronger.

The timing of the tagged birds' arrival and departure in staging areas suggests that attendance may be timed to correspond with upwelling-driven production. In the northern Pacific stopover region, the upwelling is driven by the California Current. In the northern part of the California Current (40.5 to $48.5^{\circ} \mathrm{N}$ ), upwelling is seasonal, occurring primarily between the months of March to October (Checkley $\&$ Barth 2009). While upwelling occurs year-round in 
the southern California Current $\left(27\right.$ to $\left.40^{\circ} \mathrm{N}\right)$, the strongest activity occurs during the spring and summer (Winant \& Dorman 1997). Our tagged birds departed this region by the end of August, before the seasonal production began to wind down. Upwelling generally occurs year-round in the stopover region in the northern Humboldt Current (4 to $16^{\circ} \mathrm{S}$ ) although it can be variable within and among years (Pennington et al. 2006, Echevin et al. 2008). In contrast, the secondary stopover area used by 3 of our birds in the southern Humboldt Current ( 30 to $40^{\circ} \mathrm{S}$ ) was in the region of the Subtropical Frontal Zone (35 to $40^{\circ} \mathrm{S}$ ) (Belkin \& Cornillon 2003, Belkin et al. 2009). This region is characterized by a pronounced seasonal upwelling that occurs between September and March (Letelier et al. 2009), corresponding to the austral spring and summer and the breeding season for resident seabirds. The 3 tagged birds that staged in this region did so in mid- to late October. The Patagonian Shelf stopover region also occurs within a highly productive marine region ( 35 to $55^{\circ} \mathrm{S}$ ) within the zone of convergence of the Brazil and Malvinas currents (Acha et al. 2004). Upwelling in this region generally occurs between October and March (Rivas et al. 2006). Four of the 5 tagged birds that staged here arrived in the second or third week of October, soon after the start of the upwelling season. Such an early arrival time with respect to the onset of seasonal production suggests that the timing of this stopover might be particularly tight.

In contrast, Arctic terns bypassed several upwellings in Central America (e.g. the gulfs of Tehuantepec, Nicoya, and Papagayo) that were not active during their migration period but rather in January to April (Legeckis 1988, McCreary et al. 1989, Brenes et al. 2003), just as they bypassed the Nazca Front, a subarea of the Humboldt system, which is most active in February (Belkin et al. 2009).

In the Southern Ocean, the birds wintered along the ice edges in the Weddell Sea and near the boundary of the Amundsen and Ross Seas, where productivity is high during December to March (Smith \& Nelson 1986). Other potentially important wintering regions may have been located farther south in the Weddell Sea in leads and open water within the ice pack, as indicated by several tags that recorded $24 \mathrm{~h}$ of continuous daylight for substantial periods of time.
Although our sample size is undeniably limited, our data suggest that the birds' migratory stopovers and arrival on the wintering grounds may be carefully timed (Fig. 7). The birds seemingly face time constraints during all phases of the migration; they must arrive within the northern California Current region before the seasonal production winds down, but if they move on to the southern sites too early, their arrival may precede the initiation of local seasonal productivity. Molting, which has not been studied extensively in this species, may impose the ultimate time constraint on the duration of Arctic tern migration. Limited evidence suggests that Arctic terns may need more than 3 mo to complete a molt during the austral summer (Voelker 1997). As their mobility and thermoregulatory abilities are likely compromised during the molt, they may need to reach a region of sustained high prey availability before the onset of molt, with sufficient time for the molt cycle to complete before the commencement of the northward migration. The position data from the single bird that returned with a complete round-trip record showed that it likely began migrating north in

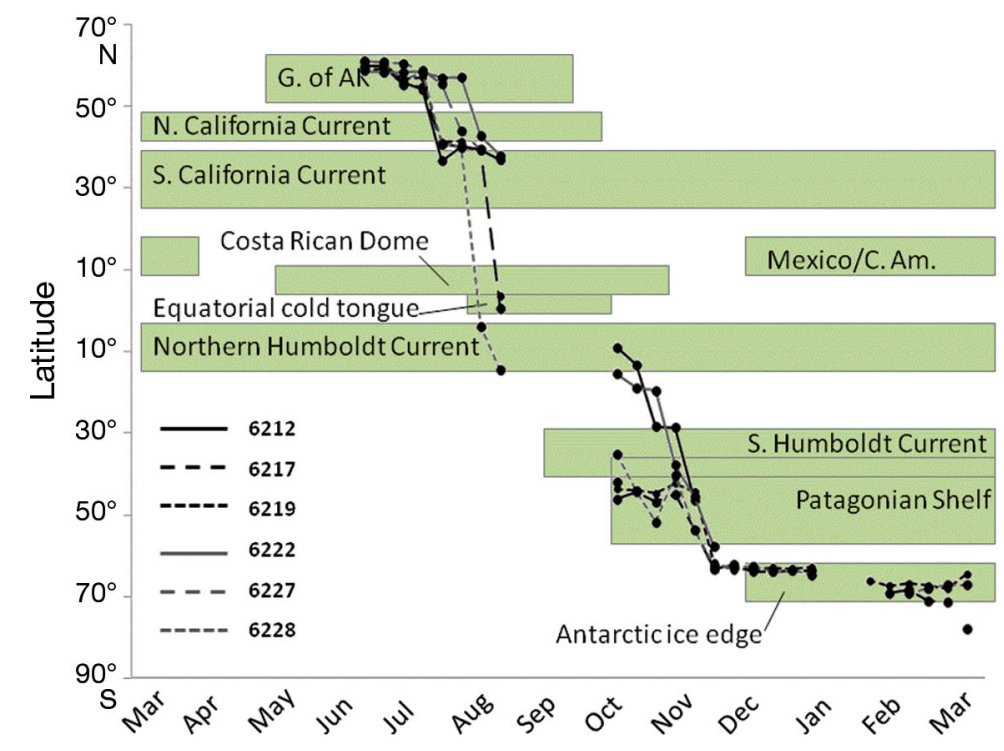

Fig. 7. Sterna paradisaea. Weekly median bird latitudes, excluding points within travel corridors, overlaid on depictions of upwelling activity within major upwelling regions by month. Green boxes $=$ the seasons of upwelling activity for major coastal regions as well as the production season for the Antarctic ice edge. We compiled upwelling characteristics (latitude range and season) from published works (Gulf of Alaska: Royer 2005; California Current: Huyer 1983, Barth et al. 2005, Checkley \& Barth 2009; Mexico/Central America upwelling: Pennington et al. 2006; Costa Rican Dome: Hofmann et al. 1981, Fiedler 2002; Equatorial cold tongue: Wyrtki 1981; Humboldt Current: Chavez \& Messie 2009; Patagonia Shelf: Rivas et al. 2006). Smith \& Nelson (1986) provided productivity data for the Antarctic ice edge. August to October: $N=6$; November to January: $N=5$; February: $N=3$. 
early March, indicating that a mid-November arrival on the wintering grounds may be crucial for optimal molt timing. Tagged birds' movements were curtailed once they arrived in wintering locations, contrary to suggestions that Arctic terns move freely about the Antarctic waters during the austral summer (Salomonsen 1967). Further, the birds' association with the ice edge from November to February may reflect not only the high quality of foraging opportunities available in this habitat type, but also the availability of floating ice to stand on. Resting on the water's surface in such cold-water environments likely confers substantial thermoregulatory costs on seabirds (Humphreys et al. 2007); floating ice may therefore be a key habitat feature for birds seeking to conserve body heat between foraging and traveling bouts. Even at lower latitudes, Arctic terns are frequently observed at sea perched on logs or basking turtles (Wynne-Edwards 1935, Murphy 1936), and the closely related common tern Sterna hirundo is also rarely observed floating on the water outside equatorial regions during the post-breeding season (Nisbet et al. 2011). Our behavioral data support this hypothesis, as floating behavior was virtually absent during the winter months.

Another striking result to emerge from this work is that these North Pacific Arctic terns exhibited a high degree of spatial overlap with North Atlantic conspecifics, as well as with other Atlantic seabirds during the austral spring and summer. Although the Patagonian Shelf staging area was not used heavily by Arctic terns tagged in Greenland and Iceland in the same year, at least 2 of the tagged Atlantic birds did visit the region during their southbound migration (Egevang et al. 2010). Arctic terns tagged in the Gulf of Maine in 2010, however, made substantial use of the region during their southbound migration (L. Welch pers. comm.). This area is also used by other seabird species migrating from the North Atlantic, including Cory's shearwaters Calonectris diomedea (Dias et al. 2010) and common terns (Nisbet et al. 2011). Additionally, other species breed in the region during the same time period, including Magellanic penguins Spheniscus magellanicus (Boersma \& Rebstock 2009), Manx shearwaters Puffinus puffinus (Guilford et al. 2009), and southern giant petrels Macronectes giganteus (Copello et al. 2011).

In addition to spatial overlap at this staging area, we found extensive overlap in the wintering grounds of Pacific Arctic terns, Arctic terns from Greenland and Iceland tagged in the same year (Egevang et al. 2010), and Arctic terns tagged in the Gulf of Maine in 2010 (L. Welch pers. comm.). Although some of the
Atlantic birds ranged farther east than our small sample of Pacific birds, birds from all 3 groups showed heavy use of the Weddell Sea region. This area supports the highest density of krill in Antarctic waters (Atkinson et al. 2004), which are likely the predominant prey item for seabirds foraging at Antarctic ice edges (Fraser et al. 1989, Santora et al. 2009). Our foraging bout data suggested a slight trend toward shorter foraging bouts during this time, which may reflect the fact that high-quality prey was readily available and easily accessible in this area.

Though geolocators have shortcomings, the insights they provide into the migration and wintering patterns of Arctic terns may be critical; at the very least this study raises concerns for the conservation of this species. First, nearly all of the birds in our sample relied on a few distinct staging areas which may be vulnerable to short term changes such as food shortages during El Nino Southern Oscillation, toxic algae blooms, and pollution events (e.g. Duffy 1983, Sydeman \& Jarman 1998, Trainer et al. 2000) and longer term perturbations such as the Pacific Decadal Oscillation, fisheries changes and anthropogenic climate change (e.g. Duffy 1993, Chavez et al. 2003, Aranciba \& Neira 2005, Fiedler \& Talley 2006). Such changes have the potential to disrupt the carefully timed migratory sequence of a large number of birds that may already be functioning near their biological limits in undertaking such a lengthy migration.

The wintering grounds present an even greater concern; at least some individuals from 3 of the 4 Arctic tern populations tagged to date wintered in the same relatively small region at the edge of the pack ice in the Weddell Sea during the austral summer. This region is currently experiencing a decline in krill abundance (Atkinson et al. 2004) and is projected to have the greatest declines in sea ice as climate change progresses in the coming decades (Lefebvre \& Goosse 2008). Major perturbations within this region could have widespread effects on the global population of Arctic terns. Finally, such extensive winter mixing of seabird populations from all over the globe could affect the evolution and transmission of avian diseases, particularly Influenza A (cf. Becker 1966).

Acknowledgements. We thank D. Boersma, P. Capece, B. Dyer, C. Egevang, R. Irons, C. Rosa, A. Rappoport, and K. Wohl for help with field work, logistics, and literature. L. Welch allowed us to preview and cite unpublished data on Arctic terns tagged in the Gulf of Maine for comparison with our birds. I. C. T. Nisbet commented on the manuscript. Funding was provided by the U.S. Fish and Wildlife Service and the Great Gull Island Essen und Fressen Society. 


\section{LITERATURE CITED}

Acha EM, Mianzan HW, Guerrero RA, Favero M, Bava J (2004) Marine fronts at the continental shelves of austral South America: physical and ecological processes. J Mar Syst 44:83-105

Aranciba H, Neira S (2005) Long-term changes in the mean trophic level of Central Chile fishery landings. Sci Mar 69:295-300

Ashmole NP, Ashmole MJ (1967) Comparative feeding ecology of sea birds of a tropical oceanic island. Peabody Mus Nat Hist Yale Univ Bull 24:1-131

> Atkinson A, Siegel V, Pakhomov E, Rothery P (2004) Longterm decline in krill stock and increase in salps within the Southern Ocean. Nature 432:100-103

Barth JA, Pierce SD, Cowles TJ (2005) Mesoscale structure and its seasonal evolution in the northern California Current System. Deep-Sea Res II 52:5-28

Bates D, Maechler M, Bolker B (2011) lme4: Linear mixedeffects models using $\mathrm{S} 4$ classes. $\mathrm{R}$ package version 0.999375-42. http://CRAN.R-project.org/package=lme4

- Becker WB (1966) The isolation and classification of tern virus: influenza A-Tern South Africa-1961. J Hyg (Lond) 64:309-320

> Behrenfeld MJ, Falkowski PG (1997) A consumer's guide to phytoplankton primary productivity models. Limnol Oceanogr 42:1479-1491

Belkin IM, Cornillon PC (2003) SST fronts of the Pacific coastal and marginal seas. Pac Oceanogr 1:90-113

Belkin IM, Cornillon PC, Sherman K (2009) Fronts in large marine ecosystems. Prog Oceanogr 81:223-236

Boersma PD, Rebstock GA (2009) Foraging distance affects reproductive success in Magellanic penguins. Mar Ecol Prog Ser 375:263-275

Brenes CL, Coen JE, Chelton DB, Enfield DB, Leon S, Ballastero D (2003) Wind driven upwelling in the Gulf of Nicoya, Costa Rica. Int J Remote Sens 24:1127-1133

Chapdelaine G, Brosseau P, Anderson R, Marsan R (1985) Breeding ecology of common and Arctic terns in the Mingan Archipelago, Quebec. Colon Waterbirds 8: 166-177

Chavez FP, Messie M (2009) A comparison of eastern boundary upwelling ecosystems. Prog Oceanogr 83:80-96

Chavez FP, Ryan J, Lluch-Cota SE, Niquen M (2003) From anchovies to sardines and back: multidecadal change in the Pacific Ocean. Science 299:217-221

Checkley DM, Barth JA (2009) Patterns and processes in the California Current System. Prog Oceanogr 83:49-64

Copello S, Dogliotti AI, Gagliardini DA, Quintana F (2011) Oceanographic and biological landscapes used by the southern giant petrel during the breeding season at the Patagonian Shelf. Mar Biol 158:1247-1257

Denlinger LM (2006) Alaska Seabird Information Series. US Fish and Wildlife Service, Migratory Bird Management Nongame Program, Anchorage, AK

> Devlin CM, Diamond AW, Kress SW, Hall CS, Welch L (2008) Breeding dispersal and survival of Arctic terns (Sterna paradisaea) nesting in the Gulf of Maine. Auk 125:850-858

> Dias MP, Granadeiro JP, Phillips RA, Alonso H, Cantry P (2010) Breaking the routine: individual Cory's shearwaters shift winter destinations between hemispheres and across ocean basins. Proc R Soc Lond B Biol Sci 278: 1786-1793

> Duffy DC (1983) Environmental uncertainty and commercial fishing: effects on Peruvian guano birds. Biol Conserv 26: 227-238

Duffy DC (1993) Stalking the Southern oscillation: environmental uncertainty, climate change and North Pacific seabirds. In: Vermeer K, Briggs KT, Morgan KH, SiegelCausey D (eds) The status, ecology and conservation of marine birds of the North Pacific. Special publication of the Canadian Wildlife Service, Ottawa

Duffy DC, McKnight A, Irons DB (in press) Trans-Andean passage of migrating Arctic terns over Patagonia. Mar Ornithol

> Dunn EH (2002) A cross-Canada comparison of mass change in birds during migration stopover. Wilson Bull 114:368-379

- Echevin V, Aumont O, Ledesma J, Flores G (2008) The seasonal cycle of surface chlorophyll in the Peruvian upwelling system: a modelling study. Prog Oceanogr 79: $167-176$

Efron B, Gong G (1983) A leisurely look at the bootstrap, the jacknife and cross-validation. Am Stat 37:36-48

Egevang C, Stenhouse IJ, Phillips RA, Petersen A, Fox JW, Silk JRD (2010) Tracking of Arctic terns Sterna paradisaea reveals longest animal migration. Proc Natl Acad Sci USA 107:2078-2081

Fetterer F, Knowles K, Meier W, Savoie M (2009) Sea Ice Index. National Snow and Ice Data Center, Boulder, CO (http://nsidc.org/data)

> Fiedler PC (2002) The annual cycle and biological effects of the Costa Rica dome. Deep-Sea Res I 49:321-338

Fiedler PC, Talley LD (2006) Hydrography of the eastern tropical Pacific: a review. Prog Oceanogr 69:143-180

Fijn RC, Hiemstra D, Phillips RA, van der Winden J (2013) Arctic terns Sterna paradisaea from The Netherlands migrate record distances across three oceans to Wilkes Land, East Antarctica. Ardea 101:3-12

Fraser WR, Pitman RL, Ainley DG (1989) Seabird and fur seal responses to vertically migrating krill swarms in Antarctica. Polar Biol 10:37-41

Guilford T, Meade J, Willis J, Phillips RA and others (2009) Migration and stopover in a small pelagic seabird, the Manx shearwater Puffinus puffinus: insights from machine learning. Proc R Soc Lond B Biol Sci 276: 1215-1223

Hahn TP, Swingle J, Wingfield JC, Ramenofsky M (1992) Adjustments of the prebasic molt schedule in birds. Ornis Scand 23:314-321

Hansen K (2001) Threats to wildlife in Greenland. Seabird Group Newsletter 89:1-2

Hatch J (2002) Arctic tern (Sterna paradisaea). The Birds of North America, Philadelphia, PA

> Hedenström A, Sunada S (1999) On the aerodynamics of moult gaps in birds. J Exp Biol 202:67-76

> Heinänen S, Rönkä M, Von Numers M (2008) Modelling the occurrence and abundance of a colonial species, the Arctic tern Sterna paradisaea in the archipelago of SW Finland. Ecography 31:601-611

Hofmann EE, Busalacchi AJ, O'Brien JJ (1981) Wind generation of the Costa Rica Dome. Science 214:552-554

Hothorn T, Bretz F, Westfall P (2008) Simultaneous inference in general parametric models. Biom J 50:346-363

> Humphreys EM, Wanless S, Bryant DM (2007) Elevated metabolic costs while resting on water in a surface feeder: the black-legged kittiwake Rissa tridactyla. Ibis 149:106-111

Hunt GL, Mehlum F, Russell RW, Irons D, Decker MB, 
Becker PH (1999) Physical processes, prey abundance and the foraging ecology of seabirds. In: Adams NJ, Slotow RH (eds) Proc 22th Int Ornithol Congr, Durban. BirdLife South Africa, Johannesburg, p 2040-2056

Huyer A (1983) Coastal upwelling in the California Current System. Prog Oceanogr 12:259-284

Klaassen M (1996) Metabolic constraints on long-distance migration in birds. J Exp Biol 199:57-64

Kress SW (1983) The use of decoys, sound recordings, and gull control, for re-establishing a tern colony in Maine. Colon Waterbirds 6:185-196

Lefebvre W, Goosse H (2008) Analysis of the projected regional sea-ice changes in the Southern Ocean during the twenty-first century. Clim Dyn 30:59-76

Legeckis R (1988) Upwelling off the Gulfs of Panama and Papagayo in the Tropical Pacific during March 1985. J Geophys Res 93:15485-15489

Lehikoinen A, Jaatinen K (2012) Delayed autumn migration in northern European waterfowl. J Ornithol 153:563-570

> Letelier J, Pizarro O, Nunez S (2009) Seasonal variability of coastal upwelling and the upwelling front off central Chile. J Geophys Res 114:C12009, doi:10.1029/2008JC005171

Liechti F (2006) Birds: blowin' by the wind? J Ornithol 147: 202-211

McCreary JP Jr, Lee HS, Enfield DB (1989) The response of the coastal ocean to strong offshore winds: with applications to circulation in the Gulf of Tehuantepec and Papagayo. J Mar Res 47:81-109

McKnight A, Sullivan KM, Irons DB, Stephensen SW, Howlin S (2008) Marine bird and sea otter population abundance of Prince William Sound, Alaska: trends following the T/V Exxon Valdez oil spill, 1989-2007. Exxon Valdez Oil Spill Restoration Project Annual Report (Restoration Project 070751), US Fish and Wildlife Service, Anchorage, AK

McKnight A, Irons DB, Allyn AJ, Sullivan KM, Suryan RM (2011) Winter dispersal and activity patterns of postbreeding black-legged kittiwakes Rissa tridactyla from Prince William Sound, Alaska. Mar Ecol Prog Ser 442: 241-253

Murphy RC (1936) Oceanic birds of South America. American Museum of Natural History, New York, NY

Nisbet ICT, Mostello CS, Veit RR, Fox JW, Afanasyev V (2011) Migrations and winter quarters of five common terns tracked using geolocators. Waterbirds 34:32-39

Pennington JT, Mahoney KL, Kuwahara VS, Kolber DD, Calienes R, Chavez FP (2006) Primary production in the eastern tropical Pacific: a review. Prog Oceanogr 69: 285-317

Phillips RA, Xavier JC, Croxall JP (2003) Effects of satellite transmitters on albatrosses and petrels. Auk 120: 1082-1090

Phillips RA, Silk JRD, Croxall JP, Afanasyev V, Briggs DR (2004) Accuracy of geolocation estimates for flying seabirds. Mar Ecol Prog Ser 266:265-272

Pinet P, Jaquemet S, Pinaud D, Weimerskirch H, Phillips RA, Le Corre M (2011) Migration, wintering distribution and habitat use of an endangered tropical seabird, Barau's petrel Pterodroma baraui. Mar Ecol Prog Ser 423: 291-302

Editorial responsibility: Rory Wilson,

Swansea, UK
R Core Development Team (2012) R: A language and environment for statistical computing. R Foundation for Statistical Computing, Vienna

Ratcliffe N (2004) Arctic tern Sterna paradisaea. In: Mitchell PI, Newton SF, Ratcliffe N, Duran TE (eds) Seabird populations of Britain and Ireland. Poyser, London, p 328-338

Rivas AL, Dogliotti AI, Gagliardini DA (2006) Seasonal variability in satellite-measured surface chlorophyll in the Patagonian Shelf. Cont Shelf Res 26:703-720

Royer TC (2005) Hydrographic responses at a coastal site in the northern Gulf of Alaska to seasonal and interannual forcing. Deep-Sea Res II 52:267-288

Salomonsen F (1967) Migratory movements of the Arctic tern (Sterna paradisea) in the southern ocean. Biol Med (Paris) 24:1-42

> Santora JA, Reiss CS, Cossio AM, Veit RR (2009) Interannual spatial variability of krill (Euphausia superba) influences seabird foraging behavior near Elephant Island, Antarctica. Fish Oceanogr 18:20-35

Smith WO, Nelson DM (1986) Importance of ice edge phytoplankton production in the southern ocean. Biomed Sci 36:251-257

Spear LB, Ainley DG (1997) Flight speed of seabirds in relation to wind speed and direction. Ibis 139:234-251

Stenhouse IJ, Egevang C, Phillips RA (2012) Transequatorial migration, staging sites and wintering area of Sabine's gulls Larus sabini in the Atlantic Ocean. Ibis 154:42-51

Stephensen SW, Zwiefelhofer DC, Howard RJ (2002) Seabird colony survey of south and east Kodiak Island, Alaska, June 2001. US Fish and Wildlife Service Report. Migratory Bird Management Anchorage, AK

Sydeman WJ, Jarman WM (1998) Trace metals in seabirds, Steller sea lions and forage fish and zooplankton from Central California. Mar Pollut Bull 36:828-832

Trainer VL, Adams NG, Bill BD, Stehr CM and others (2000) Domoic acid production near California coastal upwelling zones, June 1998. Limnol Oceanogr 45:1818-1833

> Tsipoura N, Burger J (1999) Shorebird diet during spring migration stopover on Delaware Bay. Condor 101: 635-644

Vandenabeele SP, Wilson RP, Grogan A (2011) Tags on seabirds: How seriously are instrument-induced behaviours considered? Anim Welf 20:559-571

Veit RR, Hunt GL Jr (1991) Broadscale density and aggregation of pelagic birds from a circumnavigational survey of the Antarctic Ocean. Auk 108:790-800

Voelker G (1997) The molt cycle of the Arctic tern, with comments on aging criteria. J Field Ornithol 68:400-412

Wanless S, Frederiksen M, Walton J, Harris MP (2009) Longterm changes in breeding phenology at two seabird colonies in the western North Sea. Ibis 151:274-285

Winant CD, Dorman CE (1997) Seasonal patterns of surface wind stress and heat flux over the Southern California Bight. J Geophys Res 102:5641-5653

Wynne-Edwards VC (1935) On the habits and distribution of birds on the North Atlantic. Proc Boston Soc Nat Hist 40: 233-346

Wyrtki K (1981) An estimate of equatorial upwelling in the Pacific. J Phys Oceanogr 14:242-263

Submitted: November 19, 2012; Accepted: July 3, 2013

Proofs received from author(s): September 10, 2013 